\title{
Morphological characterisation of three isolates of Heterorhabditis Poinar, 1976 from the 'Irish group' (Nematoda: Rhabditida: Heterorhabditidae) and additional evidence supporting their recognition as a distinct species, H. downesi n. sp.
}

\author{
S. Patricia Stock ${ }^{1 *}$, Christine T. Griffin ${ }^{2} \&$ Ann M. Burnell ${ }^{2}$ \\ ${ }^{1}$ Department of Nematology, University of California Davis. One Shields Ave., Davis, CA 95616-8668, USA \\ ${ }^{2}$ Institute of Bioengineering and Agroecology, Department of Biology, National University of Ireland, Maynooth, \\ Co. Kildare, Ireland \\ *Present address: Department of Plant Pathology, University of Arizona, 1140 E. South Campus Drive, Tucson, \\ AZ 85721-0036, USA
}

Accepted for publication 19th March, 2001

\begin{abstract}
The morphological variation of three representative isolates of the 'Irish group' of Heterorhabditis was examined. First generation hermaphrodites were characterised by having a blunt and mucronate tail. Females (second generation) and third-stage infective juveniles were also distinguished by the morphology of the tail and the presence of a refractile projection in the tail tip. Males were characterised by the position of the excretory pore and by the value of ratio SW. These morphological features do not fit the description of currently recognised Heterorhabditis species, and provide additional evidence in support for the consideration of the Irish group as a new species. A description of this species, as $H$. downesi n. sp., is provided.
\end{abstract}

\section{Introduction}

Entomopathogenic nematodes of the family Heterorhabditidae Poinar, 1976 are obligate and lethal parasites of insects. The only free-living stage is the third-stage infective juvenile (IJ), which is symbiotically associated with enteric bacteria of the genus Photorhabdus Boemare et al., 1993. The IJs penetrate into the haemocoel of the host either from the gut or by abrading the intersegmental membranes of the insect by using a dorsal tooth. Once in the haemocoel of the insect, the IJs release the bacterial cells, which multiply and digest the host tissues, thereby providing suitable nutrient conditions for nematode growth and development. The insect host dies rapidly, usually within 2 days of the initial penetration of the nematodes. The nematodes resume development, moult to the $\mathrm{J} 4$ stage and reach adulthood within three days (in H. bacteriophora Poinar, 1976) when cultured in vivo in larvae of the greater wax moth Galleria mellonella at $23{ }^{\circ} \mathrm{C}$ (Wang \& Bedding, 1996). Nematode repro- duction continues for at least two generations until the nutrient status of the cadaver deteriorates, whereupon adult development is suppressed and IJs accumulate and emerge into the soil where they may survive for several months in the absence of a suitable host.

Heterorhabditids are effective biological control agents of several insect pests (Berry et al., 1997; Gerritsen et al., 1998; Shields et al., 1999; Long et al., 2000; Mannion et al., 2000). Thus, interest in studying these nematodes has increased dramatically in recent years, not only to address aspects related to biological control, but also regarding basic research areas such as ecology, biodiversity, evolution, biochemistry, symbiosis and molecular genetics (review by Burnell \& Stock, 2000).

The Heterorhabditidae currently comprise one genus, Heterorhabditis Poinar, 1976, with nine recognised species, H. bacteriophora Poinar, 1976 (typespecies); H. megidis Poinar, Jackson \& Klein, 1987; H. zealandica Poinar, 1990; H. indicus Poinar, Karunakar \& David, 1992; H. argentinensis Stock, 
1993; H. hawaiiensis Gardner, Stock \& Kaya, 1994; H. brevicaudis Liu, 1994; H. marelatus Liu \& Berry, 1996 and H. poinari Kakulia \& Mikaia, 1997. However, the taxonomic status of some of these species is currently being reviewed (Stock et al., unpublished).

Surveys for heterorhabditids, which have been conducted in many parts of the world, indicate that these nematodes have a global distribution (Hominick et al., 1996; Griffin et al., 1999; Stock et al., 1999).

Studies conducted in Europe indicate that three Heterorhabditis types are present in this continent, $H$. bacteriophora, the north-west European (NWE) (considered to be $H$. megidis) and the 'Irish group' (Smits et al., 1991; Griffin et al., 1994). H. bacteriophora isolates have been recovered in Spain, southern France, Italy, central Germany, Hungary and Moldavia, suggesting this species is dominant in southern and central Europe (Smits et al., 1991; De Doucet \& Gabarra, 1994; Grenier et al., 1996; Griffin et al., 1999). NWE type isolates have been reported from the Netherlands, Poland, the south of England, Belgium, northern Germany, Denmark and Estonia, (Smits et al., 1991; Hominick et al., 1995; Miduturi et al., 1996; Griffin et al., 1999). Irish type isolates were originally recovered in Ireland (Griffin et al., 1991, 1994), but were subsequently reported in Britain (Griffin et al., 1994; Hominick et al., 1995), Hungary and Denmark (Griffin et al., 1999). Additionally, a new Heterorhabditis species, H. poinari, has been reported from Georgia (Kakulia \& Mikaia, 1997).

Molecular evidence (RFLP profiles and IEF protein electrophenograms) strongly indicates the Irish type isolates represent a separate species (Smits et al., 1991; Joyce et al., 1994a, b). Moreover, crosshybridisation tests have demonstrated that the Irish type isolates are reproductively isolated from other Heterorhabditis species (Dix et al., 1994; Griffin et al., 1994; Joyce et al., 1994b). Likewise, a molecular phylogenetic study, based on ITS-1 rDNA sequence data, by Adams et al. (1998) indicated the Irish type of Heterorhabditis (isolate K122) was a distinct species.

In spite of this cumulative evidence, the taxonomic status of the Irish group of Heterorhabditis has not yet been implicitly settled. No studies have been carried out to describe the morphological variability (if any) among these isolates and their differences to known Heterorhabditis species.

In this study we examined the morphological variation of three representative isolates of the Irish type of Heterorhabditis, providing additional evidence in support for their consideration as a distinct species. A description of this new species is herein presented.

\section{Materials and methods}

Three isolates representing the Irish type of Heterorhabditis were selected for this study. One of these isolates, K122, was the first isolate recovered in this group; therefore, it will be considered as the type isolate. This isolate was recovered from grasslands in Wexford, Ireland (Griffin et al., 1991, 1994). The remaining isolates studied are from continental Europe. Isolate EU94 was collected from an open coniferous forest with ground oak, roses and grass in Hornbaek, Denmark (Griffin et al., 1999), and isolate EU349 was collected from a roadside verge with trees in Kesckemet, Hungary (Griffin et al., 1999).

All isolates were propagated in vivo with last instar larvae of Galleria mellonella at $22 \pm 3{ }^{\circ} \mathrm{C}$. Insect cadavers were dissected on days 3-5 to recover first generation hermaphrodites and on days 7-9 to recover second generation adults, following Kaya \& Stock (1997). Third-stage infective juveniles were harvested during the first 2 days after initial emergence (approximately days 13-18) from the cadaver, as suggested by Nguyen \& Smart (1996).

For each of the studied isolates, 20 specimens from each stage (first-generation hermaphrodites, secondgeneration males, second-generation females and third-stage infective juveniles) were randomly collected from $10 \mathrm{G}$. mellonella cadavers (Hominick et al., 1997). Nematodes were examined live or heatkilled in $60{ }^{\circ} \mathrm{C}$ Ringer's solution. Nematodes were fixed in triethanolamine formalin (TAF) (Courtney et al., 1955) and processed to anhydrous glycerine for mounting (Seinhorst, 1959). Specimens were mounted on glass slides supported with glass rods to avoid their flattening. Observations were made from live and mounted specimens using a Nikon Eclipse E600 microscope equipped with differential interference contrast optics. Specimen measurements were made using Scion Image software (Frederick, Maryland, USA) that was calibrated using a stage micrometer. Selection of morphometric characters was done according to Stock \& Kaya (1996) and Stock (1997). Illustrations were prepared from digitised camera lucida images.

The following abbreviations have been used in the text or tables: $\mathrm{L}=$ total body length; $\mathrm{ABW}=$ anal or cloacal body width; EP = excretory pore position; $\mathrm{ES}=$ oesophagus length; GS $=\mathrm{GuL} / \mathrm{SpL}$; GuL $=\mathrm{gu}-$ 
bernaculum length; $\mathrm{MBW}=$ maximum body width; $\mathrm{ML}=$ mucro length; $\mathrm{NR}=$ nerve-ring position; ratio $\mathrm{a}=\mathrm{L} / \mathrm{MBW}$; ratio $\mathrm{b}=\mathrm{L} / \mathrm{ES}$; ratio $\mathrm{c}=\mathrm{L} / \mathrm{TL}$; ratio $\mathrm{d}=\mathrm{EP} / \mathrm{ES}$; ratio e $=\mathrm{EP} / \mathrm{TL} ; \mathrm{SpL}=$ spicule length (measured along the curvature in a line along the centre of the spicule); $\mathrm{StL}=$ stoma length; $\mathrm{StW}=$ stoma width; $\mathrm{SW}=\mathrm{SpL} / \mathrm{ABW} ; \mathrm{TL}=$ tail length (measured without considering the extra cuticular sheath of the second stage juvenile); TRL = testis reflexion length; $\mathrm{V}=$ vulva position from anterior end expressed as percentage of $\mathrm{L}$.

\section{Heterorhabditis downesi n. sp.}

Type-host: Unknown. Nematodes recovered by soil baiting technique (Bedding \& Akhurst, 1975).

Type-locality: Grassland at Curracloe, Co. Wexford, Ireland. This type-locality corresponds to the sampling site where isolate K122 (the type-isolate) was recovered (see Griffin et al., 1994).

Type-specimens: Holotype, second generation male (UCDNC 3816), allotype second-generation female (UCDNC 3817), 15 paratype hermaphrodites (UCDNC 3818-3820), 15 males (UCDNC 38213823), 15 third-stage infective juvenile (UCDNC 3824-3826) deposited at the University of California Davis Nematode Collection. Additional paratype material (5 hermaphrodites, 4 second-generation males, 4 second-generation females and 5 third-stage infective juveniles deposited at CABI Bioscience Nematode Collection, UK Centre (Egham), UK.

Etymology: This species is named for Professor Martin J. Downes, a colleague and active collaborator in the isolation of the Irish type of Heterorhabditis.

\section{Description (Figures 1-3)}

The following description is based on the examination of morphological and morphometric features of $3 \mathrm{Het}$ erorhabditis isolates considered in this study.

Adults. Head truncated or slightly rounded (Figure $1 \mathrm{~A}, \mathrm{~F})$. Six distinct protruding pointed lips surrounding oral aperture. Each lip bears one labial papilla. Amphidial apertures inconspicuous, pore-like. Stoma short, wide. Cheilostom short with refractile rhabdions; gymnostom and stegostom reduced (Figure 2A). Oesophagus rhabditoid. Corpus cylindrical; metacorpus not differentiated. Isthmus short. Basal bulb pyriform with reduced valve. Nerve-ring located in middle of isthmus. Excretory pore located at level of basal bulb (Figure 1A).

Hermaphrodite (first generation). With ovotestis. Vulva located near middle of body. Vulval lips protruding, with anterior lip larger than posterior lip (Figures 1B, 2B). Postanal swelling well developed (Figures 1C, 2C). Tail terminus blunt and mucronate (Figures 1C, 2C).

Female (second generation). Amphidelphic. Vulva situated near middle of body. Vulval lips slightly protruding (Figures 1D, 2D). Tail conoid, narrowing towards end into refractile spike-like structure (Figures 1E, 2E). Postanal swelling slightly developed (Figure 1E).

Male (second generation). Monorchic. Testis anteriorly reflexed. Spicules paired, symmetrical, straight or arcuate, with pointed tips (Figures 1G, 2F,H). Manubrium (head) square, well set off from lamina. Calamus distinct. Lamina with one internal rib. Velum absent. Gubernaculum thin, about half size of spicules. Bursa open, peloderan, attended by complement of 9 pairs of bursal rays (papillae). Arrangement of papillae is as follows: 12 () 33 (Figure 1G). Pairs 4 and 7 bent dorsally. Pair 8 does not reach rim of bursa (Figure $2 \mathrm{G})$.

Third-stage infective juvenile (IJ). Ensheathed in cuticle of second-stage juvenile (J2) (Figure 3A). Cuticle of $\mathrm{J} 2$ with longitudinal ridges throughout most of body length and tessellate pattern in most anterior part of body (seen with DIC light microscopy). Body slender, gradually tapering posteriorly. IJ with prominent cuticular dorsal tooth (seen with DIC light microscopy) (Figure 3B,C). Amphidial opening small, pore-like. Nerve-ring located in middle of isthmus. Excretory pore located posteror to basal bulb (Figure 1H). Lateral field with 2 ridges (as seen with DIC microscopy and confirmed by cross-sections) (Figure 3D). Tail short, conoid, tapering to small spike-like tip (Figures 1I-K, 3E-G). Morphology of tail tip variable, with most characteristic shape (80\% of examined IJs from 3 studied isolates) shown in Figures 1I,J, 3E,F.

\section{Dimensions}

Holotype male (isolate K122): $\mathrm{L}=877 \mu \mathrm{m} ; \mathrm{MBW}=$ $33 \mu \mathrm{m} ; \mathrm{StL}=7 \mu \mathrm{m} ; \mathrm{StW}=4.5 \mu \mathrm{m} ; \mathrm{ES}=100 \mu \mathrm{m}$; $\mathrm{NR}=62.5 \mu \mathrm{m} ; \mathrm{EP}=90 \mu \mathrm{m} ; \mathrm{TL}=32 \mu \mathrm{m} ; \mathrm{ABW}$ $=23 \mu \mathrm{m} ; \mathrm{TRL}=131 \mu \mathrm{m} ; \mathrm{SpL}=42 \mu \mathrm{m} ; \mathrm{GuL}=$ $19 \mu \mathrm{m} ; \mathrm{GS}=0.45 ; \mathrm{SW}=1.8$. 

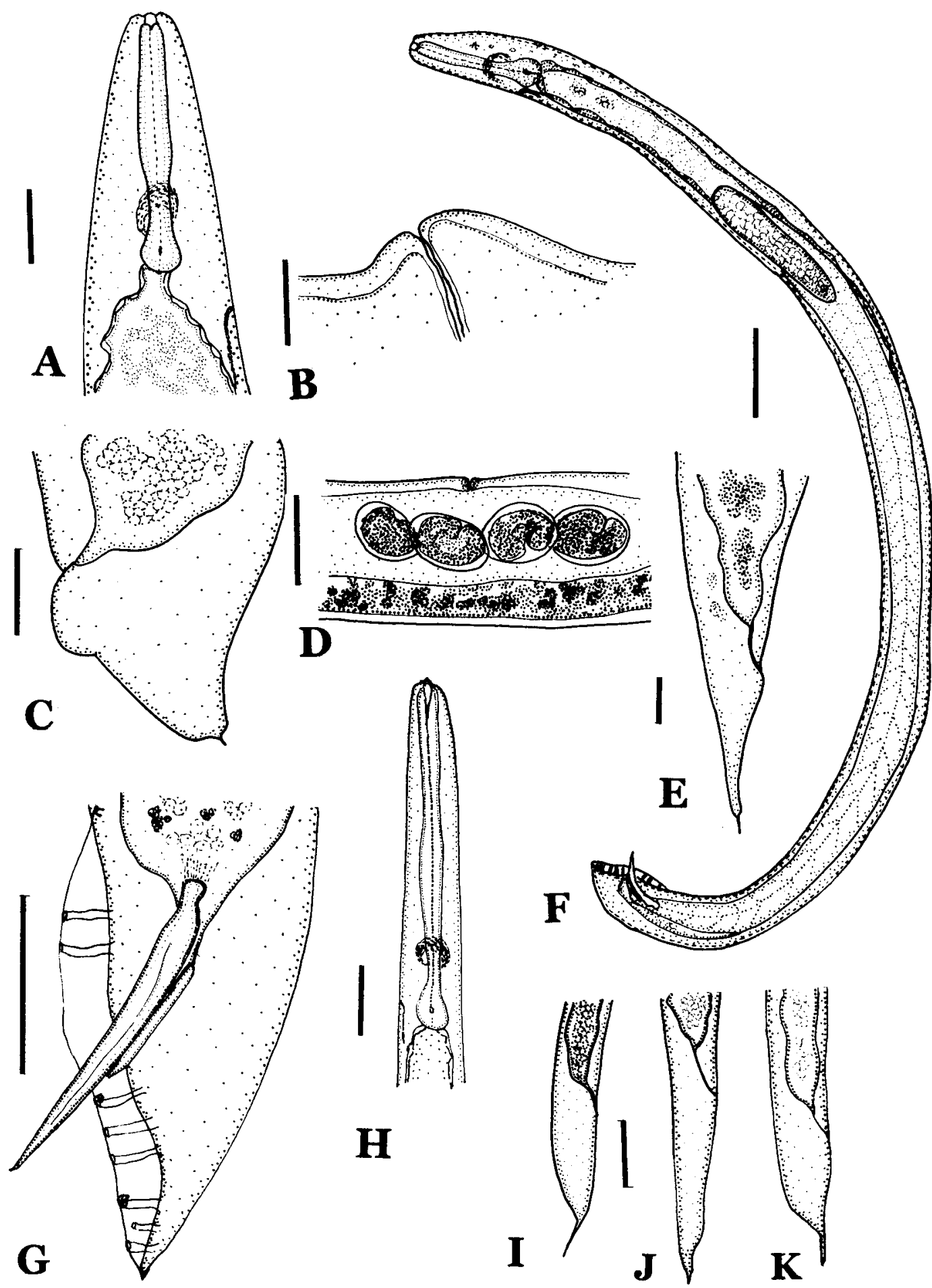

Figure 1. Heterorhabditis downesi $\mathrm{n}$. sp. A. Anterior end of hermaphrodite; B. Vulva of hermaphrodite; C. Tail of hermaphrodite in lateral view; D. Vulva of female; E. Tail of female in lateral view; F. Male; entire worm; G. Male tail in lateral view; H. Anterior end of third-stage infective juvenile; I-K. Tail of third-stage infective juvenile. Scale-bars: A,D-F, $50 \mu \mathrm{m}$; B,C,G,H, $25 \mu \mathrm{m}$; I-K, $18 \mu \mathrm{m}$ 

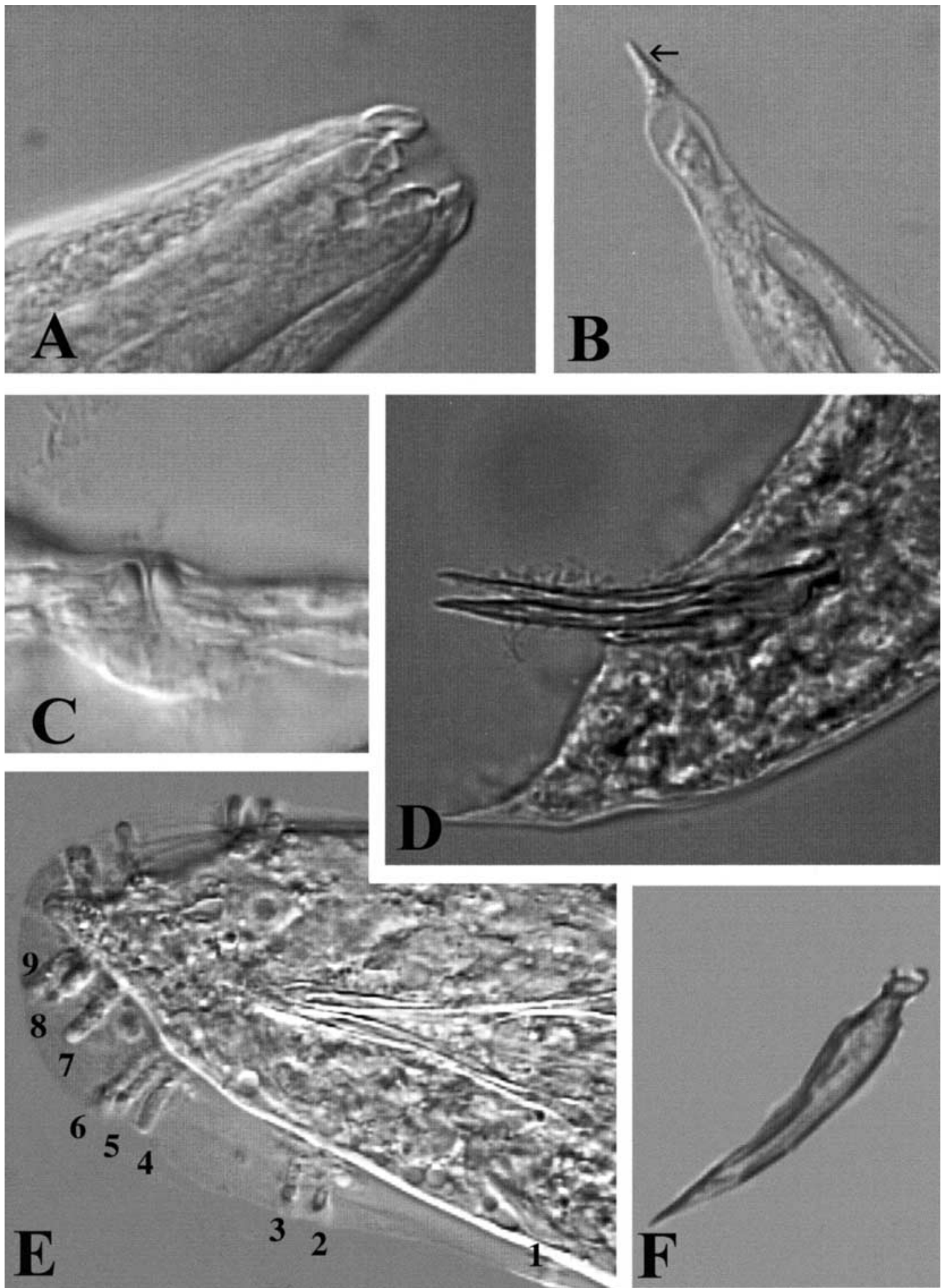

Figure 2. Adult stages of Heterorhabditis downesi n. sp. A. Anterior region of first generation hermaphrodite showing stoma region; B. Tail of first generation hermaphrodite showing mucro (arrow); C. Vulval lips of second generation female; D. Tail of male in lateral view; E. Tail of male in ventral view showing arrangement of bursal rays; F. Spicule. Scale: $1 \mathrm{~cm}=$ A, $8 \mu \mathrm{m}$; B, $2 \mu \mathrm{m}$; C, $8 \mu \mathrm{m}$; D-F, $1 \mu \mathrm{m}$. 

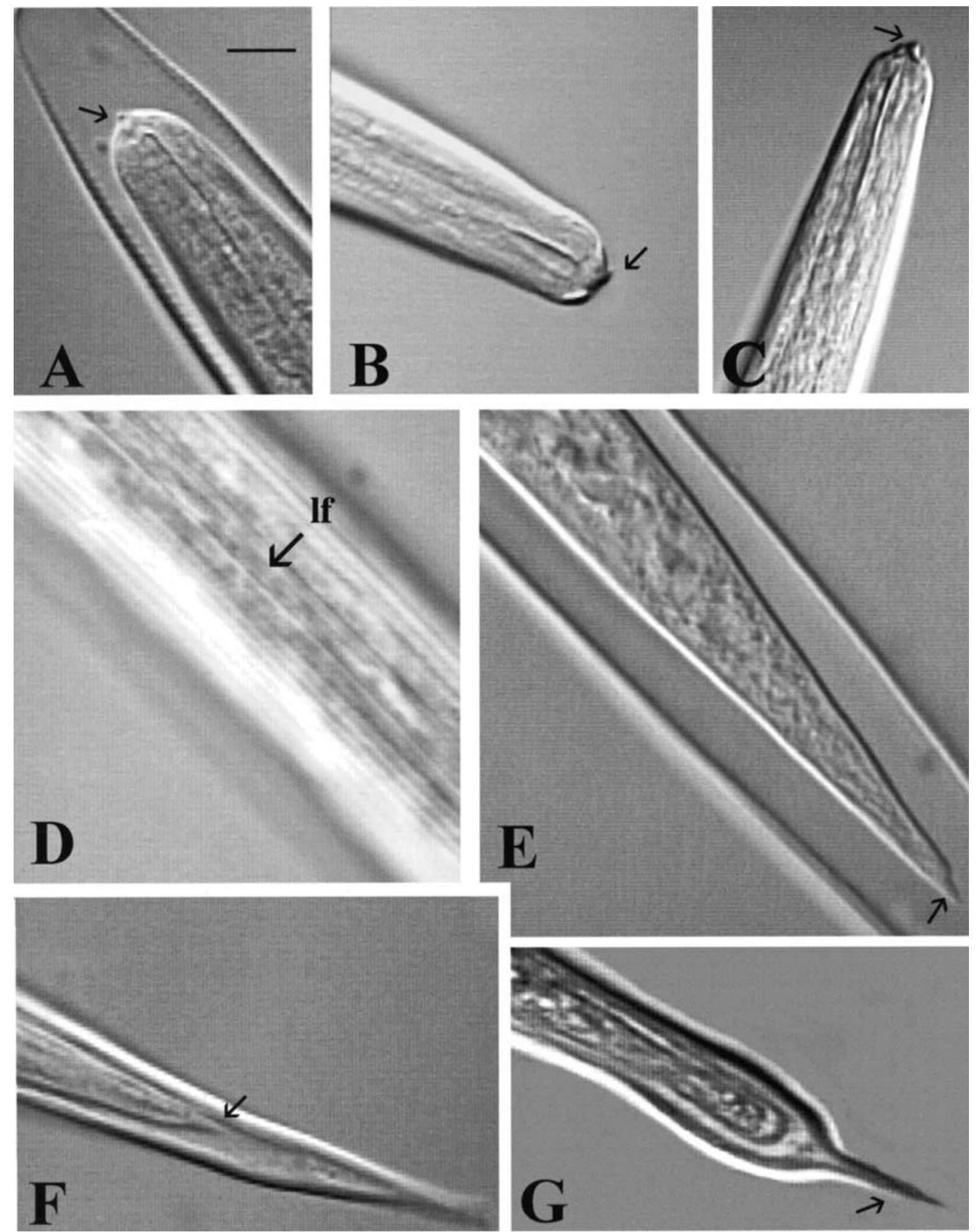

Figure 3. Third-stage infective juvenile of Heterorhabditis downesi n. sp. A-C. Anterior end showing cuticular tooth (arrows); D. Cuticle showing lateral field pattern (lf); E-F. Tail showing most typical shape of the 'spike-like' tip (arrows). G. Atypical tail tip. Scale-bars: A-C,E-G, $15 \mu \mathrm{m} ; \mathrm{D}, 10 \mu \mathrm{m}$ 


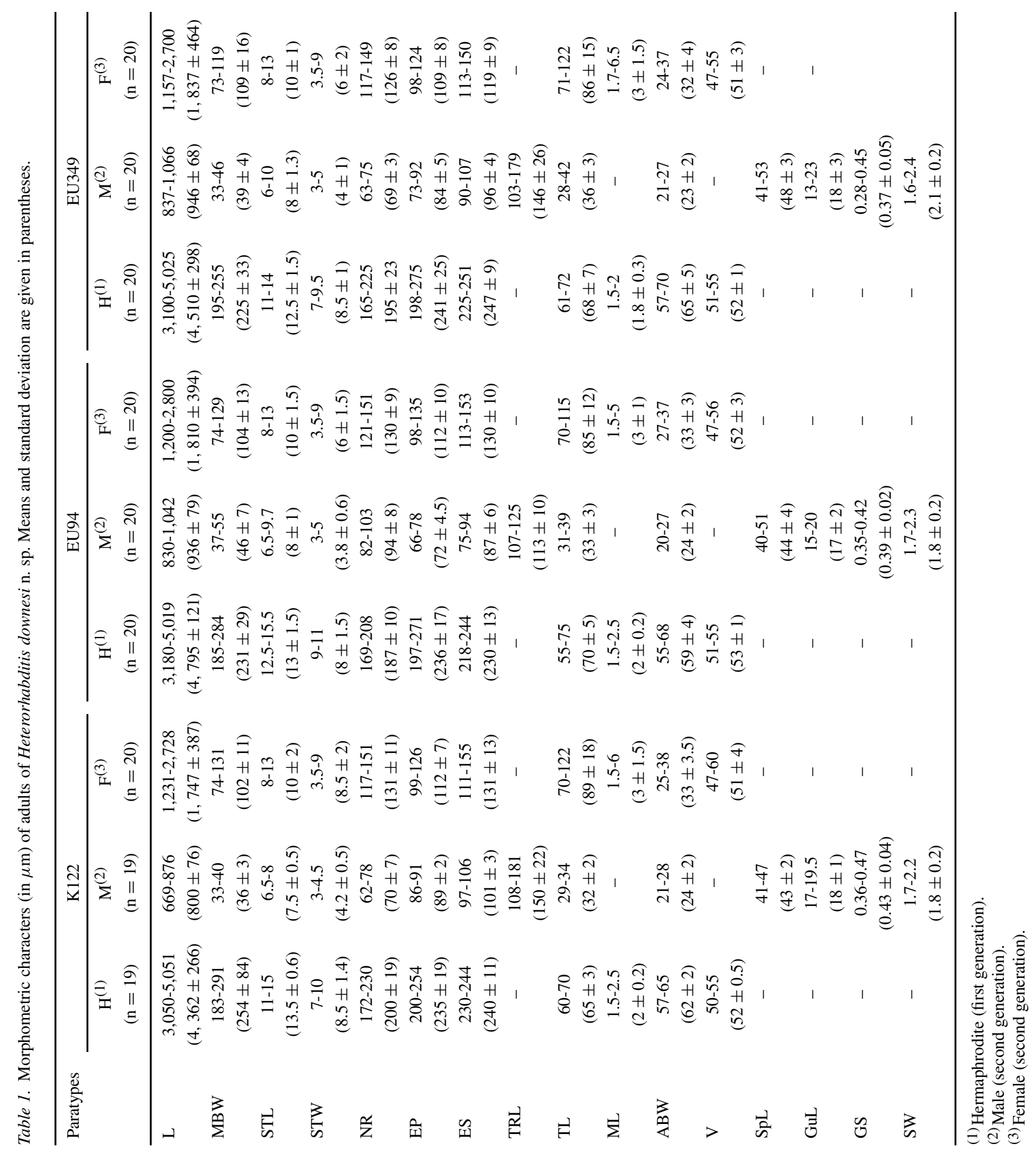


Allotype second-generation female (isolate K122): L $=1,500 \mu \mathrm{m} ; \mathrm{MBW}=102 \mu \mathrm{m} ; \mathrm{StL}=9 \mu \mathrm{m} ; \mathrm{StW}=$ $4 \mu \mathrm{m} ; \mathrm{ES}=128 \mu \mathrm{m} ; \mathrm{NR}=110 \mu \mathrm{m} ; \mathrm{EP}=131 \mu \mathrm{m}$; $\mathrm{TL}=76 \mu \mathrm{m} ; \mathrm{ML}=4 \mu \mathrm{m} ; \mathrm{ABW}=29 \mu \mathrm{m} ; \mathrm{AE}-\mathrm{V}=$ $712 \mu \mathrm{m} ; \mathrm{V}=47.5$.

Paratypes (hermaphrodites, males and females, and third-stage infective juvenile): See Tables 1 and 2.

\section{Diagnosis and relationships}

Heterorhabditis downesi n. sp. can be separated from other species in the genus by a combination of morphological and morphometric traits of all life stages (Tables 3, 4). Hermaphrodites of $H$. downesi n. sp. can be distinguished from all currently recognised Heterorhabditis species by having a blunt and mucronate tail.

Males of the new species can be separated from other Heterorhabditis species by having the narrowest body width. Additionally, males of this species are characterised by the position of the excretory pore, which is more anteriorly located than other described Heterorhabditis species. The spicules of $H$. downesi $\mathrm{n}$. sp. resemble those of $H$. marelatus and $H$. megidis in having a square-shaped manubrium (head), which is well set off from the lamina by a thin calamus (neck), but can be separated from these species by the value of ratio SW (mean: 1.8) (Table 3).

The tail of the females (second generation) of $H$. downesi n. sp. resembles that of $H$. marelatus. However, females of the new species can be distinguished by the presence of a conspicuous refractile mucronated process. The body length of third-stage infective juveniles of $H$. downesi n. sp. (mean: $637 \mu \mathrm{m}$ ) is practically indistinguishable from $H$. argentinensis $(657 \mu \mathrm{m})$ and $H$. marelatus $(640 \mu \mathrm{m})$. The average tail length of $H$. downesi n. sp. $(68 \mu \mathrm{m})$ is similar to that of $H$. marelatus $(65 \mu \mathrm{m})$. H. brevicaudis is also characterised by having a short tail $(75.5 \mu \mathrm{m})$. However, comparisons between the new species and $H$. brevicaudis are difficult because the original description does not provide details of how the tail length of the third-stage infective juveniles was measured (i.e. considering or not the extra cuticular sheath from the second-stage juvenile). But the infective juveniles of the new species can be distinguished from these and the rest of the recognised Heterorhabditis species by the morphology of the tail (which is pointed and tapers to a short spike-like tip) and/or the value of the ratio c (Table 4).
Table 2. Morphometric characters (in $\mu \mathrm{m}$ ) of third-stage infective juveniles of Heterorhabditis downesi n. sp. Means and standard deviation are given in parentheses.

\begin{tabular}{|c|c|c|c|}
\hline Paratypes & $\begin{array}{c}\mathrm{K} 122 \\
(\mathrm{n}=20)\end{array}$ & $\begin{array}{c}\text { EU94 } \\
(\mathrm{n}=20)\end{array}$ & $\begin{array}{l}\text { EU349 } \\
(\mathrm{n}=20)\end{array}$ \\
\hline $\mathrm{L}$ & $\begin{array}{c}588-692 \\
(637 \pm 32)\end{array}$ & $\begin{array}{c}521-691 \\
(607 \pm 51)\end{array}$ & $\begin{array}{c}520-741 \\
(597 \pm 54)\end{array}$ \\
\hline MBW & $\begin{array}{c}15-22 \\
(18 \pm 2)\end{array}$ & $\begin{array}{c}14-25 \\
(19 \pm 4)\end{array}$ & $\begin{array}{c}15-24 \\
(20 \pm 3)\end{array}$ \\
\hline NR & $\begin{array}{c}96-105 \\
(101 \pm 3)\end{array}$ & $\begin{array}{c}74-115 \\
(92 \pm 9)\end{array}$ & $\begin{array}{c}82-108 \\
(92 \pm 6)\end{array}$ \\
\hline EP & $\begin{array}{c}96-128 \\
(115 \pm 8)\end{array}$ & $\begin{array}{c}88-123 \\
(107 \pm 9)\end{array}$ & $\begin{array}{c}97-123 \\
(106 \pm 9)\end{array}$ \\
\hline ES & $\begin{array}{c}126-141 \\
(135 \pm 4)\end{array}$ & $\begin{array}{c}121-136 \\
(128 \pm 4)\end{array}$ & $\begin{array}{c}115-143 \\
(127 \pm 8)\end{array}$ \\
\hline $\mathrm{TL}$ & $\begin{array}{c}62-74 \\
(68 \pm 4)\end{array}$ & $\begin{array}{c}54-78 \\
(65 \pm 9)\end{array}$ & $\begin{array}{c}51-83 \\
(64 \pm 10)\end{array}$ \\
\hline ABW & $\begin{array}{c}9-14 \\
(12 \pm 1)\end{array}$ & $\begin{array}{c}9-14 \\
(12 \pm 1)\end{array}$ & $\begin{array}{c}10-15 \\
(12 \pm 2)\end{array}$ \\
\hline Ratio a & $\begin{array}{c}29-42 \\
(35 \pm 4)\end{array}$ & $\begin{array}{c}26-38 \\
(33 \pm 4)\end{array}$ & $\begin{array}{c}25-37 \\
(31 \pm 3)\end{array}$ \\
\hline Ratio b & $\begin{array}{c}4.4-5.3 \\
(4.7 \pm 0.3)\end{array}$ & $\begin{array}{c}4.3-5.2 \\
(4.7 \pm 0.3)\end{array}$ & $\begin{array}{c}4.3-5.2 \\
(4.7 \pm 0.3)\end{array}$ \\
\hline Ratio c & $\begin{array}{c}8.5-10.5 \\
(9.5 \pm 0.5)\end{array}$ & $\begin{array}{c}8-11 \\
(9 \pm 1)\end{array}$ & $\begin{array}{c}7.6-11 \\
(9.5 \pm 1)\end{array}$ \\
\hline Ratio d & $\begin{array}{c}0.76-0.98 \\
(0.85 \pm 0.05)\end{array}$ & $\begin{array}{c}0.66-0.97 \\
(0.84 \pm 0.1)\end{array}$ & $\begin{array}{c}0.8-0.90 \\
(0.85 \pm 0.04)\end{array}$ \\
\hline Ratio e & $\begin{array}{c}1.6-1.8 \\
(1.7 \pm 0.1)\end{array}$ & $\begin{array}{c}1.2-2.1 \\
(1.7 \pm 0.3)\end{array}$ & $\begin{array}{c}1.3-2.2 \\
(1.7 \pm 0.2)\end{array}$ \\
\hline
\end{tabular}

\section{Discussion}

Heterorhabditis species have essentially been delimited on the basis of Linnaean species concepts. Morphological and morphometric characters of adult stages (specifically second generation males) and third-stage infective juveniles, have been used for diagnostic purposes and to assess their identity as morphospecies (Poinar, 1976; Poinar 1990; Stock, 1993; Liu \& Berry, 1996; Stock et al, 1996; Stock \& Kaya, 1996). However, because of the paucity of morphological traits in the Heterorhabditidae, other approaches have been applied for their delimitation and diagnosis at the species level. For instance, different molecular methods, such as starch gel electrophoresis, restriction enzyme analyses (RFLPs), isoelectric focussing (IEF), random amplified polymorphic DNA (RAPD) markers and sequence data, have been successfully used to identify and infer phylogenetic relationships 


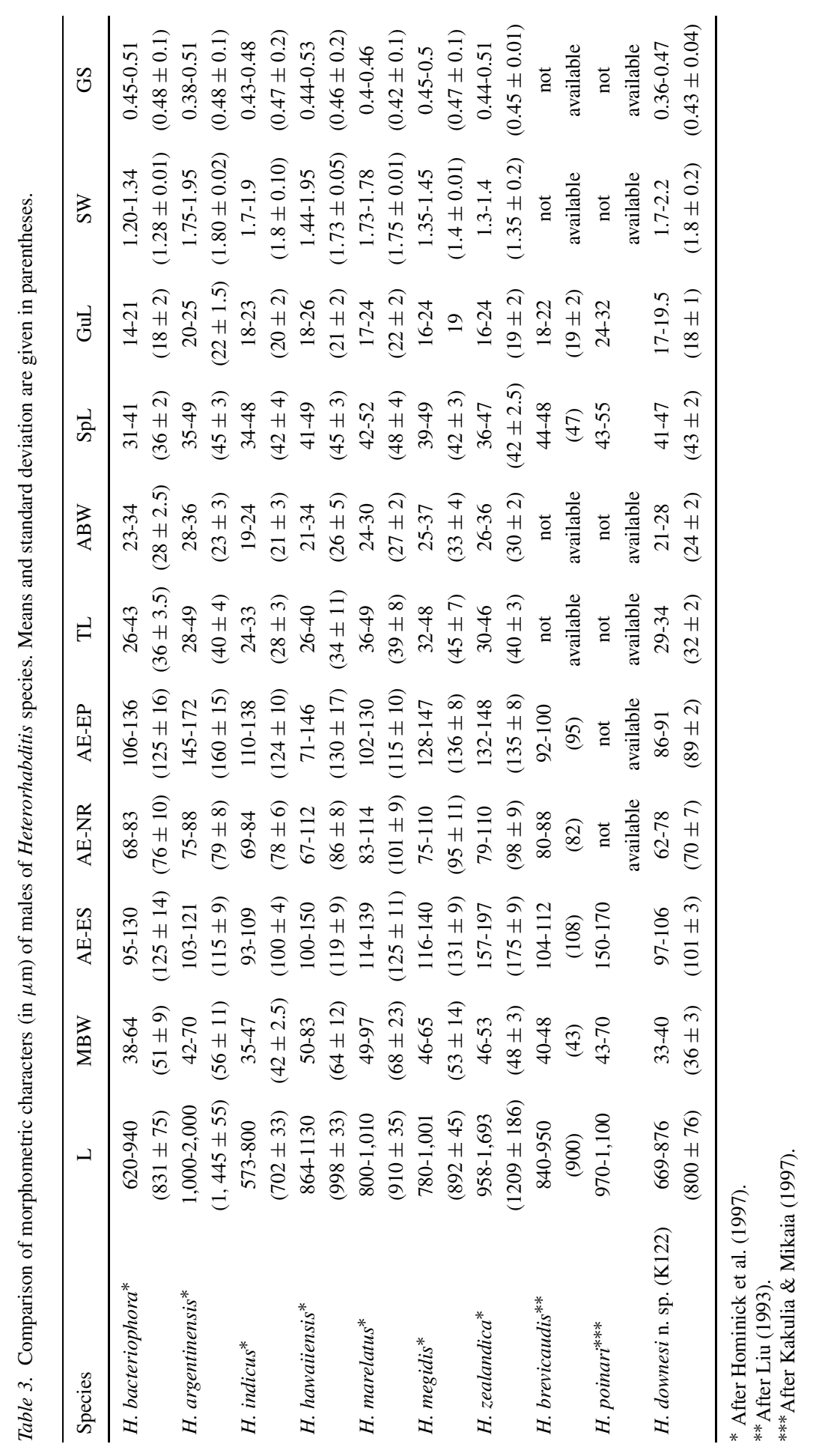




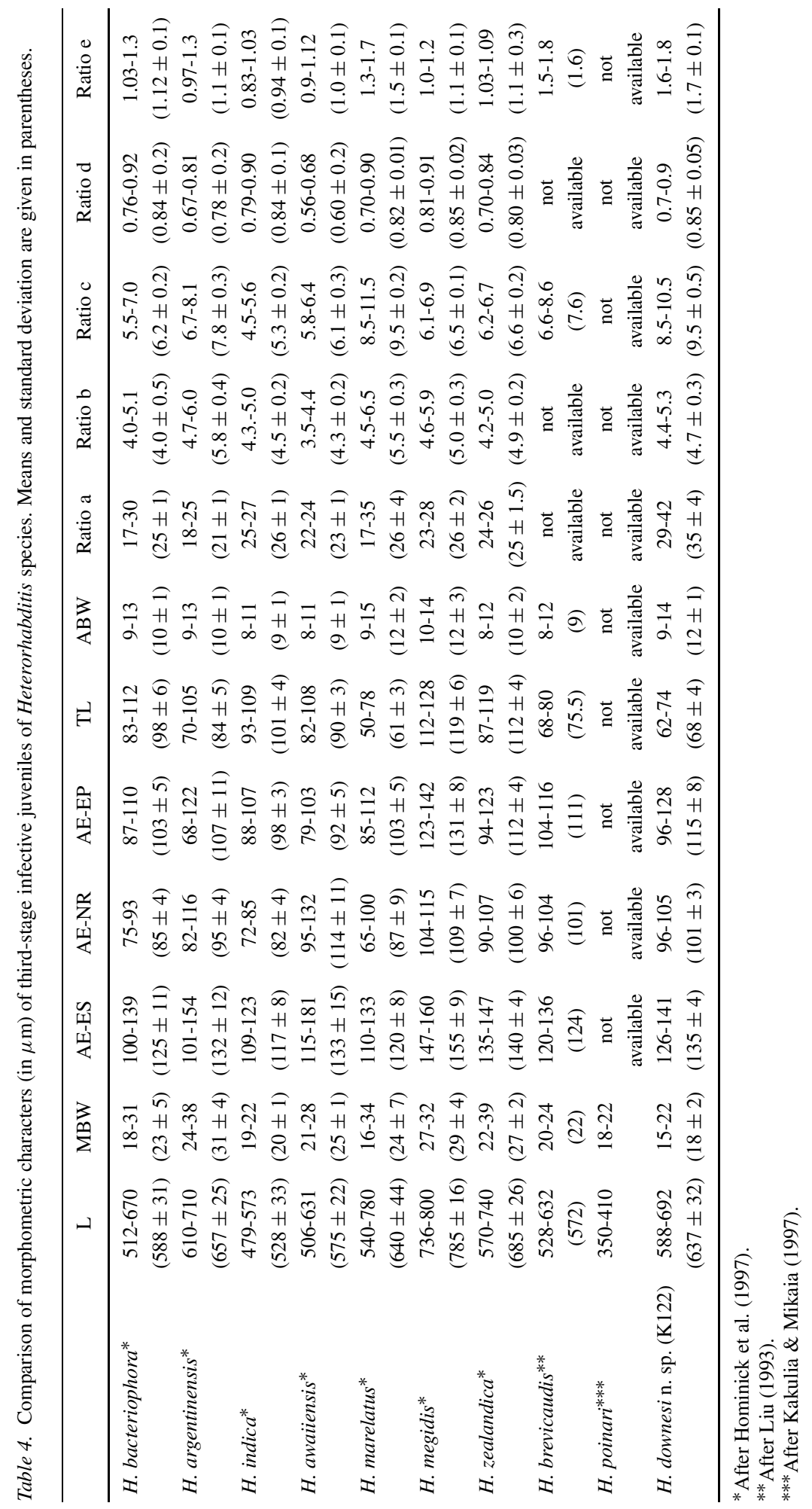


among Heterorhabditis species (Akhurst, 1987; Smits et al., 1991; Joyce et al., 1994a,b; Gardner et al., 1994; Liu \& Berry, 1996; Adams et al., 1998). In addition to this, Heterorhabditis species have also been tested for adherence to the biological species concept by conducting cross-hybridisation tests (Dix et al., 1992; Griffin et al., 1994).

With particular reference to the 'Irish group', preliminary studies based on interpretation of IEF gel electrophoresis indicated that members of this group were distinctive from other species of Heterorhabditis (see Joyce et al., 1994a). Joyce et al. (1994b) carried out an RFLP study of PCR amplified fragments of the rDNA internal transcribed spacer (rDNA ITS) region and the mtDNA cytochrome oxidase subunit II gene of a range of Heterorhabditis isolates and species. These authors found that the members of the 'Irish group' were distinct from other species of Heterorhabditis in their rDNA ITS HinfI restriction profiles and in their $S s p$ I and DraI profiles for the mtDNA COII gene. In a recent study based on interpretation of sequence data (rDNA ITS-1), Adams et al. (1998) also indicated that the 'Irish group' of Heterorhabditis represents a distinct species. Furthermore, cross-breeding experiments between Irish group and other Heterorhabditis species/isolates have provided additional support for the recognition of the 'Irish group' as single species (Griffin et al., 1994, 1999).

However, until now, no morphological studies had been undertaken to examine the morphological characteristics of the Irish group isolates. With this background in mind, in the present study we selected three representative isolates of the 'Irish group' from three different geographical locations, including the original isolation site in Ireland, and two additional locations from continental Europe (Hungary and Denmark). Our observations indicated that there were no significant differences in the morphology or morphometric values $(\mathrm{P}<0.05)$ between these three isolates. However, when compared with currently recognised species in this genus, several unique morphological features were observed. For instance, females (second generation) and third-stage infective juveniles were characterised by the morphology of the tail and the presence of a refractile projection in the tail tip. Males of the new species were also distinguished from other members of the genus by the value of ratio SW.

These diagnostic morphological and morphometric features, together with formerly published molecular evidence and hybridisation tests, show that this species is unique and does not fit the description of currently recognised Heterorhabditis species; therefore, it is considered new and named $H$. downesi $\mathrm{n}$. sp.

In the past, morphological traits of males and infective juveniles have been emphasised in the diagnosis and identification of Heterorhabditis species (Stock \& Kaya, 1996; Hominick et al., 1997). However, in this study we have shown that most of the 'key' diagnostic features in the Irish Heterorhabditis, were provided by hermaphrodites and females. Similar observations were made by Stock et al. (1996) and Stock (1997) in the description of H. marelatus (=H. hepialius Stock et al., 1996), where hermaphrodites and females provided useful diagnostic features.

These observations suggest that it is very important that no preconceptions are made when identifying species in Heterorhabditis and that all life stages should be carefully examined.

\section{References}

Adams, B.J., Burnell, A.M. \& Powers, T.O. (1998) A phylogenetic analysis of Heterorhabditis (Nemata: Rhabditidae) based on internal transcribed spacer 1 DNA sequence data. Journal of Nematology, 30, 22-39.

Akhurst, R.J. (1987) Use of starch gel electrophoresis in the taxonomy of the genus Heterorhabditis (Nematoda: Heterorhabditidae). Nematologica, 33, 1-9.

Bedding, R.A. \& Akhurst, R.J. (1975) A simple technique for the detection of insect parasitic rhabditid nematodes in soil. Nematologica, 21, 109-110.

Berry, R.E., Liu, J. \& Groth, E. (1997) Efficacy and persistence of Heterorhabditis marelatus (Rhabditida, Heterorhabditidae) against root weevils (Coleoptera, Curculionidae) in strawberry. Environmental Entomology, 26, 465-470.

Burnell, A.M. \& Stock, S.P. (2000) Heterorhabditis, Steinernema and their bacterial symbionts - lethal pathogens of insects. Nematology, 2, 31-42.

Courtney, W.D., Polley, D. \& V.L. Miller (1955). TAF, an improved fixative in nematode technique. Plant Disease and Reproduction, 39, 570-571.

De Doucet, M.M.A. \& Gabarra, R. (1994) On the occurrence of Steinernema glaseri (Steiner, 1929) (Steinernematidae) and Heterorhabditis bacteriophora Poinar, 1976) (Heterorhabditidae) in Catalogne, Spain. Fundamental and Applied Nematology, 17, 441-443.

Dix, I., Burnell, A.M., Griffin, C.T., Joyce, S.A., Nugent, M.J. \& Downes M.J. (1992) The identification of biological species in the genus Heterorhabditis (Nematoda: Heterorhabditidae) by cross-breeding second generation amphimictic adults. Parasitology, 104, 509-518.

Dix, I., Koltai, H., Glazer, I. \& Burnell, A.M. (1994) Sperm competition in mated first generation hermaphrodite females of the HP88 strain of Heterorhabditis (Nematoda: Heterorhabditidae) and progeny sex ratios in mated and unmated females. Fundamental and Applied Nematology, 17, 17-27. 
Gardner, S.L., Stock, S.P. \& Kaya, H.K. (1994) A new species of Heterorhabditis from the Hawaiian islands. Journal of Parasitology, 80, 100-106.

Gerritsen, L.J.M., Wiegers, G.L. \& Smits, P.H. (1998) Pathogenicity of new combinations of Heterorhabditis spp. and Photorhabdus luminescens against Galleria mellonella and Tipula oleracea. Biological Control, 13, 9-15.

Grenier, E., Bonifassi, E., Abad, P. \& Laumond, C. (1996) Use of species specific satellite DNAs as diagnostic probes in the identification of Steinernematidae and Heterorhabditidae entomopathogenic nematodes. Parasitology, 113, 483-489.

Griffin, C.T., Moore, J.F. \& Downes, M.J. (1991) Occurrence of insect-parasitic nematodes (Steinernematidae, Heterorhabditidae) in the Republic of Ireland. Nematologica, 37, 92-100.

Griffin, C.T., Joyce, S.A., Dix, I., Burnell, A.M. \& Downes, M.J. (1994) Characterisation of the entomopathogenic nematode Heterorhabditis (Nematoda: Heterorhabditidae) from Ireland and Britain by molecular and cross-breeding techniques, and the occurrence of the genus in these islands. Fundamental and Applied Nematology, 17, 245-253.

Griffin, C. T., Dix, I., Joyce, S.A., Burnell, A.M. \& Downes, M.J. (1999) Isolation and characterisation of Heterorhabditis spp. (Nematoda: Heterorhabditidae) from Hungary, Estonia and Dennmark. Nematology, 1, 321-332.

Hominick, W.M., Reid, A.P. \& Briscoe, B.R. (1995) Prevalence and habitat specificity of steinernematid and heterorhabditid nematodes isolated during soil surveys of the UK and the Netherlands. Journal of Helminthology, 69, 27-32.

Hominick, W.M., Reid, A. P., Bohan, D.A. \& Briscoe, B.R. (1996) Entomopathogenic nematodes: biodiversity, geographical distribution and the convention on biological diversity. Biocontrol Science and Technology, 6, 317-331.

Hominick, W.M., Briscoe, B.R., del Pino, F.G., Heng, J., Hunt, D.J., Kozodoy, E., Mrácek, Z., Nguyen, K.B., Reid, A. P., Spiridonov, S., Stock, S.P., Sturhan, D., Waturu, C. \& Yoshida, M. (1997) Biosystematics of entomopathogenic nematodes: Current status, protocols and definitions. Journal of Helminthology, 71, 271-298.

Joyce, S.A., Griffin, C.T. \& Burnell, A.M. (1994a) The use of isoelectric focusing and polyacrylamide gel electrophoresis of soluble proteins in the taxonomy of the genus Heterorhabditis (Nematoda: Heterorhabditidae) Nematologica, 40, 601-612.

Joyce, S.A., Burnell, A.M. \& Powers, T.O. (1994b) Characterisation of Heterorhabditis isolates by PCR amplification of segments of mtDNA and rDNA genes. Journal of Nematology, 26, 260-270.

Kakulia, G. \& Mikaia, N. (1997) New species of the nematode Heterorhabditis poinari sp. nov. (Rhabditida, Heterorhabditidae). Bulletin of the Georgian Academy of Sciences, 155, 457-459.

Kaya, H.K. \& Stock, S.P (1997) Techniques in insect nematology. In: Lacey, L.A. (Ed.) Manual of techniques in insect pathology. Biological Techniques Series. San Diego, London: Academic Press, pp. 281-324.

Liu, J. \& Berry, R.E. (1996) Heterorhabditis marelatus n. sp. (Rhabditida: Heterorhabditidae) from Oregon. Journal of Invertebrate Pathology, 67, 48-54

Long, S.J., Richardson, P.N. \& Fenlon, J.S. (2000) Influence of temperature on the infectivity of entomopathogenic nematodes (Steinernema and Heterorhabditis spp.) to larvae and pupae of the vine weevil Otiorhynchus sulcatus (Coleoptera, Curculionidae). Nematology, 2, 309-317.

Mannion, C.M., Winkler, H.E., Shapiro, D.I. \& Gibb, T. (2000) Interactions between halofenozide and the entomopathogenic nematode Heterorhabditis marelatus for control of Japanese beetle (Coleoptera, Scarabaeidae) larvae. Journal of Economic Entomology, 93, 48-53.

Miduturi, J.S., Matata, G.J. M. \& Waeyenberge, L. (1996) Naturally occurring entomopathogenic nematodes in the province of WestFlanders, Belgium. Journal of Helminthology, 70, 319-327.

Nguyen, K.B. \& Smart, G.C., Jr (1996) Identification of entomopathogenic nematodes in the Steinernematidae and Heterorhabditidae (Nemata: Rhabditidae). Journal of Nematology, 28, 286-300.

Poinar, G.O., Jr (1976) Description and biology of a new insect parasitic rhabditoid, Heterorhabditis bacteriophora n. gen. $\mathrm{n}$. sp. (Rhabditida; Heterorhabditidae n. fam.). Nematologica, 21, 463-470.

Poinar, G.O., Jr (1990) Taxonomy and biology of Steinernematidae and Heterorhabditidae. In: Gaugler, R. \& Kaya, H.K. (Eds) Entomopathogenic nematodes in biological control. Boca Raton, Florida: CRC Press, pp. 23-60.

Seinhorst, J.W. (1959) A rapid method for the transfer of nematodes from fixative to anhydrous glycerin. Nematologica, 4, 117-128.

Shields, E.J., Testa, A, Miller, J.M. \& Flanders, K.L. (1999) Field efficacy and persistence of the entomopathogenic nematodes Heterorhabditis bacteriophora Oswego and $H$. bacteriophora $\mathrm{NC}$ on alfalfa snout beetle larvae (Coleoptera: Curculionidae). Environmental Entomology, 28, 128-136.

Smits, P.H., Groenen, J.T.M. \& de Raay, D.G. (1991) Characterization of Heterorhabditis isolates using DNA restriction fragment length polymorphism. Revue de Nématologie, 14, 445-454.

Stock, S.P. (1993) A new species of the genus Heterorhabditis (Nematoda: Heterorhabditidae) parasitic of Graphognathus sp. larvae (Coleoptera: Curculionidae) from Argentina. Research \& Reviews in Parasitology, 53, 103-107

Stock, S.P. (1997) Heterorhabditis hepialius Stock, Strong \& Gardner, 1996 a junior synonym of $H$. marelatus Liu \& Berry, 1996 (Rhabditida: Rhabditidae) with a redescription of the species. Nematologica, 43, 455-463.

Stock, S.P. \& Kaya, H.K. (1996) A multivariate analysis of morphometric characters of Heterorhabditis species (Nemata: Heterorhabditidae) and the role of morphometrics in the taxonomy of species of the genus. Journal of Parasitology, 82, 806-813.

Stock, S.P., Strong, D.R. \& Gardner, S.L. (1996) Identification of Heterorhabditis (Nematoda: Heterorhabditidae) from California with a new species isolated from the larvae of the ghost moth Hepialis californicus (Lepidoptera: Hepialidae) from the Bodega Bay Natural Reserve. Fundamental and Applied Nematology, 19, 585-592.

Stock, S.P., Pryor, B.M. \& Kaya, H.K. (1999) Distribution of entomopathogenic nematodes (Steinernematidae and Heterorhabditidae) in natural habitats in California, USA. Biodiversity and Conservation, 8, 535-549.

Wang, J. \& Bedding, R.A. (1996) Population development of Heterorhabditis bacteriophora and Steinernema carpocapsae in the larvae of Galleria mellonella. Fundamental and Applied Nematology, 19, 363-367. 